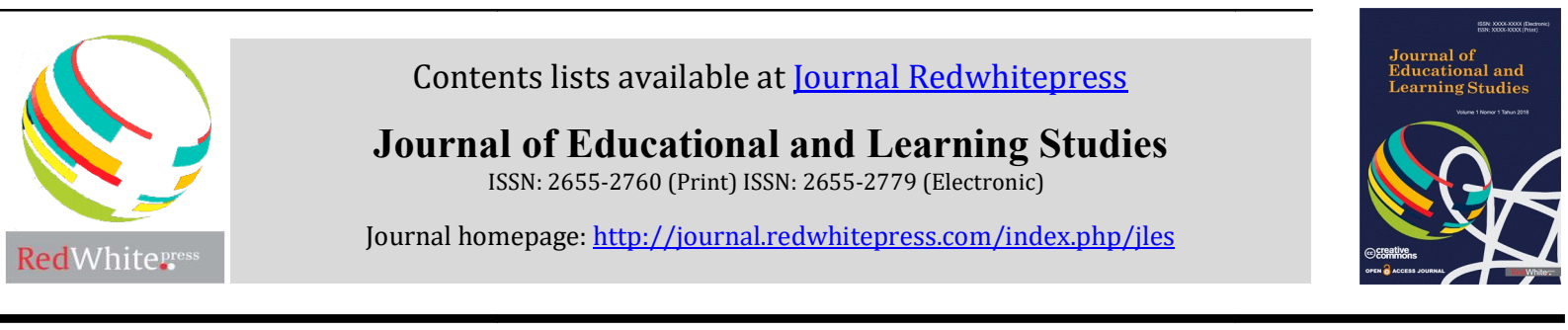

\title{
Perception and Attitude of Malaysian Underprivileged Students in Learning ESL: A Preliminary Case Study
}

\author{
Zulaika Abd Aziz ${ }^{1}$, Abu Yazid Abu Bakar ${ }^{2}$ \\ ${ }^{12}$ Universiti Kebangsaan Malaysia
}

\section{Article Info \\ Article history: \\ Received Mar $12^{\text {th }} 2019$ \\ Revised Apr $3^{\text {rd }} 2019$ \\ Accepted Mei $10^{\text {th }} 2019$}

\section{Keyword:}

Attitude

ESL

Perception

Underprivileged students

\begin{abstract}
Perception and attitude are linked with each other to influence second language learning. In local ESL context, perception and attitude of learners towards learning English language are heavily depending on their environment, economic status and experience. The new National Education Blueprint (2013-2025) has outlined five system aspirations in achieving 50\% of reduction in achievement gaps that include urban-rural, socioeconomic and gender.This calls for immediate attention to students from low economic status in effort to close the achievement gap and improve the teaching-learning strategies to cater their specific needs. This preliminary study investigates the underprivileged students from orphanages in the area of Selangor, Malaysia. A total of 30 respondents aged between 13 to 17 years old took part in this study. Data was collected via a questionnaire survey and interviews and was analysed using descriptive statistics. The findings suggest that students have positive attitude in ESL learning and they were aware of its importance. However, their interests in ESL learning are limited due to poor access of resources. Hence, these students have little opportunities to learn the language. Some recommendations are made for future policy and practice.
\end{abstract}

\section{Corresponding Author:}

Abu Yazid Abu Bakar,

Universiti Kebangsaan Malaysia

Email: : yazid3338@ukm.edu.my

\section{Introduction}

Language is an important means for communication in our daily activities. Through language, we can express our opinion, thoughts, ideas, and feelings. Nowadays, the acquisition of English Language is a must as English is globally used. Considering this need, English as a Second Language (ESL) is taught since kindergarten years in Malaysia. With the increasing need and ceaseless interest in learning English as a second language in Malaysia, it is important to study and understand the factors that can affect the learning process. Among some of the most prominent factors are the students' perceptions and attitudes towards the learning process of English language at school.

Perception is defined as something that is being observed and what is said about it (Ahen, 2009; Campbell 1967). It varies from person to person, in which every individuals assign different meanings to what they perceive. And the meanings might change for a certain person. One might change one's perspective or simply make things mean something else. Attitude, on the other hand, according to The Concise Oxford Dictionary, refers to a "settled behaviour, as indicating opinion", or a "settled mode of thinking". It is defined as "a hypothetical construct used to explain the direction and persistence of human behaviour." or refers to "our feelings and shapes our behaviours towards learning", or a psychological tendency that may reflect both beliefs 
and feelings (Al-Tamimi \& Shuib, 2009;Eagly \& Chaiken, 2007). Thus, behaviour is tied to attitude, as the latter highly affects and manifests itself in the former.

Research works in language learning indicated that learners with positive attitudes were always having more advantage compared to those with negative attitudes (Ghazali, 2016) (Holmes \& Wilson, 2017). Students' attitude is an integral part of learning; thus, it should become an essential component of second language learning pedagogy. It is important to gain more information regarding students' attitude in order to understand their thoughts and feelings toward learning English in the classroom. It is also paramount to create and raise students' awareness of practices and use the language in their daily life. A knowledgeable and proficient student will be able to gather, process, publish and communicate information receives in the classroom within a range of contexts across all learning areas. It could prepare the student to use the language and apply the skills in the forms of reading, listening, writing, and speaking. Indeed, knowing one's attitudes and motivation are the best ways to identify the preferences in learning second language.

Therefore, attitude plays an important role in second language learning as it determines to a large extent the learners' behaviours, for example action taken to learn, or efforts exerted, during the learning process. Nevertheless, positive or negative attitude is rooted from an individual perception towards certain matters or objects. This means that the input gains from an individual's perception will influence the attitude of that particular individual toward certain matters or objects, as he or she has made his or her own judgement through the observation. In other words, one's attitude is the result of one's individual perception. Therefore, in learning English as second language, if a student perceived that learning the language is important, he or she will passionately enjoy the learning process. If his or her perception is otherwise, the student may portray a negative attitude in the classroom.

\section{Research Background}

The individual perception and attitude of ESL learners may be influenced by various environmental factors such as the socioeconomic status of family, geographical location of school, and community/societal norms where they lived in. In other words, underprivileged students can be defined as students' population who are being deprived through social or economic conditions of a civilized society. Individuals who are underprivileged are at disadvantage in many aspects, especially in term of education. As a matter of fact, an underprivileged individual might not even afford to go to school. It means that this individual does not have access to services and opportunities which the general population enjoys. In a formal learning process, underprivileged students' perception and attitude can be greatly influenced, and may hindrance their learning. To illustrate, when a student comes from low-income family, he or she will not has the advantage to learn in a comfortable and supportive environment; thus, their motivation may drop and end up quitting school. Students who were considered underprivileged (coming from family with low SES, schooling in remote areas, or living in an unsupportive community) may have different perception and attitude in learning English in comparison to their peers with opposite backgrounds (Ming, 2004).

However, there are limited numbers of study on underprivileged students' perception and attitude in learning English. There are many studies on students' perception and attitude but most scholars usually focusing on secondary students with lower grade, or among university students (PENGNATE, 2014). Studies regarding university students usually found that most students have positive attitude towards English while for secondary students they mostly have moderate level of motivation and attitude towards English. A particular study investigated motivations and attitude for learning English among year six students in Malaysian primary rural school had found out that the students appeared to have a positive attitude towards learning English language, whereby the results demonstrated that the participants had the interest and desire to excel in their English classes (Yunus \& Abdullah, 2011). Another study indicated that students with negative attitudes towards learning English literature are Malays, males, does not speak another language at home, does not have siblings or parents who speak English, comes from a lower income family of less than RM500 per month, low marks for final English Form Four examination, and comes from an arts class in a rural school (Ghazali, 2016). In short, students that come from a lower income family and rural schools have negative attitudes towards studying literature in English.

As research works on perception and attitude of local underprivileged students toward learning English as a Second Language (ESL) are far and rare in between, this research is designed as a preliminary case study in order to understand the students' views to make the process of learning English is more effective despite of their deprived conditions. It is conducted with main objective to identify local underprivileged students' perception toward English which affected their attitude in learning the language. In other words, the 
researchers want to find out the students' struggles, interests, and desires in learning English as a Second Language (ESL). Specifically, the objectives of this study were to:

a. determine underprivileged students' perception towards learning ESL

b. determine underprivileged students' attitude towards learning ESL

c. examine underprivileged students' views to improve teaching-learning methods to match with the students' needs

\section{Method}

This is a quantitative study using the cross-sectional survey questionnaire design. As an initial case study, a minimum total of 30 (Yin, 2001)Form Three students were recruited from a school in the area of Selangor, Malaysia as respondents. They have been identified as underprivileged students due to socioeconomic status of the families.

The questionnaire was adapted from the original survey developed by a Saudi Arabian researcher (Alkaff, 2013). It consisted of 22 items, answered using a 5-point Likert Scale. The collected data was descriptively analysed to answer the research questions as follows:

a. What are the students' overall views in learning ESL?

b. What is the level of difficulty in learning ESL? If it is, which part of learning the language is difficult? What do the students do to improve their learning of ESL

\section{Results and Discussions}

As shown in Table 1, most of the participants agreed that learning English is fun (66.66\%); only a small percentage of the participants disagreed (20\%), while the percentage of those who strongly disagreed, or said that they did not know was $13.33 \%$. Similarly, the percentage of the participants who agreed that they like to listen to people speaking English (73.33\%) was much larger than the percentage of those who disagreed or said they did not know which both have the same percentage of $13.33 \%$. Moreover, no participants strongly disagreed. Likewise, a large percentage $(70 \%)$ of the participants agreed that they really wanted to learn English, and percentage of $16.66 \%$ said that they did not know while $13.33 \%$ of the students disagreed. Furthermore, as in the responses to the previous statements, strong disagreement remained $0 \%$. The statement "I dislike English" elicited $20 \%$ of agreement compared to $56.66 \%$ of disagreement, while $23.33 \%$ of the participants said that they did not know. The statement "I only learn English because it is compulsory in school" elicited more disagreement (66.66\%) than agreement (16.66\%). Interestingly, the total number of those who agreed and those who strongly agreed matched the figure of those who said they that did not know $(16.66 \%)$. As for the image of those who spoke English, a large percentage of $73.33 \%$ agreed that when someone spoke English, it showed that he/she is educated, with $6.66 \%$ strongly agreed while $6.66 \%$ disagreed. The $13.33 \%$ difference was equal to the percentage of those who stated that they did not know. However, most of the participants strongly agreed, or agreed, that speaking English well could create a good impression with the total high percentage of $93.33 \%$. The percentage of those who did not know was only $13.33 \%$. Surprisingly none of them disagree about the statement ( $0 \%$ ).Same goes for strong disagreement. Moreover, all participants either strongly agreed, or agreed, that learning English was important for their future, with a higher percentage of those who agreed $(73.33 \%)$ and strongly agreed with $13.33 \%$. Similar to the responses of the previous statement, virtually all the participants agreed that learning English could help them find better job opportunities, with a higher percentage of those who agreed $(73.33 \%$ ) and a total percentage of $80 \%$ representing general agreement. Only $13.33 \%$ said that they did not know, and a small number of percentage $6.66 \%$ said they disagree. Also, a total high percentage of $80 \%$ agreed that learning English was essential to further the study in a higher level, with $13.33 \%$ of them strongly agreed. On the other hand, only $6.66 \%$ disagreed, and $13.33 \%$ stated they did not know. There was no strong disagreement $(0 \%)$. Furthermore, there was an overall agreement among participants that they needed English when they travelled abroad, and the percentage of those who strongly agreed (76.66\%) exceeded that of those who agreed (23.33\%). However, it seems that students have different opinion on statement "I need English when I search the internet" with more of them were on disagreement side (43.33\%) although the difference was not big with the percentage of those who agreed was $36.66 \%$. The rest said that they did not know (20\%). 
Table 1: Students' overall views on learning ESL

\begin{tabular}{|c|c|c|c|c|c|}
\hline Statement & $\begin{array}{l}\text { Strongly } \\
\text { Agree }\end{array}$ & Agree & $\begin{array}{l}\text { Don't } \\
\text { Know }\end{array}$ & Disagree & $\begin{array}{l}\text { Strongly } \\
\text { Disagree }\end{array}$ \\
\hline Learning and speaking English is fun & $\begin{array}{c}5 \\
(16.66 \%)\end{array}$ & $15(50 \%)$ & $\begin{array}{c}4 \\
(13.33 \%)\end{array}$ & $6 \quad(20 \%)$ & 0 \\
\hline $\begin{array}{l}\text { I like to listen to people speaking } \\
\text { English }\end{array}$ & $2(6.66 \%)$ & $\begin{array}{c}20 \\
(66.66 \%)\end{array}$ & $\begin{array}{c}4 \\
(13.33 \%)\end{array}$ & $\begin{array}{c}4 \\
(13.33 \%)\end{array}$ & 0 \\
\hline I really want to learn English & $1(3.33 \%)$ & $\begin{array}{c}20 \\
(66.66 \%)\end{array}$ & $\begin{array}{c}4 \\
(13.33 \%)\end{array}$ & $\begin{array}{c}4 \\
(13.33 \%)\end{array}$ & 0 \\
\hline I dislike English & 0 & $6 \quad(20 \%)$ & $\begin{array}{c}4 \\
(13.33 \%)\end{array}$ & $\begin{array}{c}20 \\
(66.66 \%)\end{array}$ & 0 \\
\hline $\begin{array}{l}\text { I only learn English because it is } \\
\text { compulsory in school }\end{array}$ & 0 & $\begin{array}{c}5 \\
(16.66 \%)\end{array}$ & $\begin{array}{c}5 \\
(16.66 \%)\end{array}$ & $\begin{array}{c}20 \\
(66.66 \%)\end{array}$ & 0 \\
\hline $\begin{array}{l}\text { When someone speaks English, it } \\
\text { shows that he/she is educated }\end{array}$ & $2(6.66 \%)$ & $\begin{array}{c}22 \\
(73.33 \%)\end{array}$ & $\begin{array}{c}4 \\
(13.33 \%)\end{array}$ & $2(6.66 \%)$ & 0 \\
\hline $\begin{array}{l}\text { Speaking English well can create a } \\
\text { good impression }\end{array}$ & $(10 \%)$ & $\begin{array}{c}25 \\
(83.33 \%) \\
\end{array}$ & $2(6.66 \%)$ & 0 & 0 \\
\hline $\begin{array}{l}\text { Learning English is important for my } \\
\text { future }\end{array}$ & $\begin{array}{c}4 \\
(13.33 \%)\end{array}$ & $\begin{array}{c}22 \\
(73.33 \%)\end{array}$ & $\begin{array}{c}4 \\
(13.33 \%)\end{array}$ & $2(6.66 \%)$ & 0 \\
\hline $\begin{array}{l}\text { Learning English can help me find } \\
\text { better job opportunities }\end{array}$ & $\begin{array}{c}4 \\
(13.33 \%)\end{array}$ & $\begin{array}{c}22 \\
(73.33 \%)\end{array}$ & $\begin{array}{c}4 \\
(13.33 \%)\end{array}$ & $2(6.66 \%)$ & 0 \\
\hline $\begin{array}{l}\text { Learning English is essential to } \\
\text { further my study }\end{array}$ & $\begin{array}{c}4 \\
(13.33 \%) \\
\end{array}$ & $\begin{array}{c}22 \\
(73.33 \%) \\
\end{array}$ & $\begin{array}{c}4 \\
(13.33 \%) \\
\end{array}$ & $2(6.66 \%)$ & 0 \\
\hline I need English when I travel abroad & $\begin{array}{c}23 \\
(76.66 \%) \\
\end{array}$ & $\begin{array}{c}7 \\
(23.33 \%) \\
\end{array}$ & 0 & 0 & 0 \\
\hline $\begin{array}{l}\text { I need English when I search in the } \\
\text { internet }\end{array}$ & $1(3.33 \%)$ & $\begin{array}{c}10 \\
(33.33 \%)\end{array}$ & $(20 \%)$ & $\begin{array}{c}10 \\
(33.33 \%) \\
\end{array}$ & 0 \\
\hline
\end{tabular}

Table 2 shows that $66.66 \%$ of the participants agreed that learning English was difficult. A slightly lower percentage disagreed (20\%), while $16.66 \%$ said that they did not know. Similarly, with regards to grammar and structure, $80 \%$ of the participants strongly agreed or agreed that both aspects were difficult for them. The total percentage which represented disagreement in general was 16.66 and only a small number of $3.33 \%$ said they did not know. A large proportion (83.33\%) of the participants strongly agreed or agreed that lack of vocabulary made understanding and communicating in English difficult. Noticeably, none of the participants have disagreement towards this statement although there were those who did not know (16.66\%).

Table 2: Level of difficulty in learning ESL and which part of it is difficult?

\begin{tabular}{lccccc}
\hline \multicolumn{1}{c}{ Statement } & $\begin{array}{c}\text { Strongly } \\
\text { Agree }\end{array}$ & Agree & $\begin{array}{c}\text { Don't } \\
\text { Know }\end{array}$ & Disagree & $\begin{array}{c}\text { Strongly } \\
\text { Disagree }\end{array}$ \\
\hline Learning English is difficult & $\begin{array}{c}5 \\
(16.66 \%)\end{array}$ & $15(50 \%)$ & $\begin{array}{c}4 \\
(13.33 \%)\end{array}$ & $6(20 \%)$ & 0 \\
\hline $\begin{array}{l}\text { I find English grammar and structure } \\
\text { difficult }\end{array}$ & $\begin{array}{c}4 \\
(13.33 \%)\end{array}$ & $\begin{array}{l}20 \\
(66.66 \%)\end{array}$ & $1(3.33 \%)$ & 5 & 0 \\
\hline $\begin{array}{l}\text { Lack of vocabulary makes } \\
\text { understanding and communicating in }\end{array}$ & $\begin{array}{c}5 \\
(16.66 \%)\end{array}$ & $\begin{array}{c}20 \\
(66.66 \%)\end{array}$ & $\begin{array}{c}5 \\
(16.66 \%)\end{array}$ & 0 & 0 \\
\begin{tabular}{l} 
English difficult \\
\hline
\end{tabular}
\end{tabular}

As for skills, it can be seen in Table 3 that all participants thought that speaking was difficult (100\%); writing came second $(86.66 \%)$, listening came third (36.66\%), while reading came last (10\%). 
Table 3: What do you consider as a difficult skill in English?

\begin{tabular}{cccc}
\hline Writing & Reading & Listening & Speaking \\
\hline $26(86.66 \%)$ & $3(10 \%)$ & $11(36.66 \%)$ & $30(100 \%)$ \\
\hline
\end{tabular}

As can be seen in Table 4, 50\% of the participants agreed that they could improve their English. Interestingly enough, a slightly smaller proportion said that they did not know (43.33\%). Only $6.66 \%$ disagreed with the statement. It was noticeable that the students had the same percentage of $33.33 \%$ for overall agreement, disagreement, and didn't know for statement "I don't have time to improve my English".

Table 4: Do you believe you can improve your English?

\begin{tabular}{lccccc}
\hline \multicolumn{1}{c}{ Statement } & $\begin{array}{c}\text { Strongly } \\
\text { Agree }\end{array}$ & Agree & $\begin{array}{c}\text { Don't } \\
\text { Know }\end{array}$ & Disagree & $\begin{array}{c}\text { Strongly } \\
\text { Disagree }\end{array}$ \\
\hline I think I can improve my English & 0 & $15(50 \%)$ & $\begin{array}{c}13 \\
(43.33 \%)\end{array}$ & $2(6.66 \%)$ & 0 \\
\hline $\begin{array}{l}\text { I don't have time to improve my } \\
\text { English }\end{array}$ & $\begin{array}{c}2 \\
(6.66 \%)\end{array}$ & $\begin{array}{c}8 \\
(26.66 \%)\end{array}$ & $\begin{array}{c}10 \\
(33.33 \%)\end{array}$ & $\begin{array}{c}(33.33 \%) \\
0\end{array}$ \\
\hline
\end{tabular}

As shown in Tables 5, when the participants were asked to state their own strategies to improve their English proficiency, surprisingly most of them chose none with the percentage of $66.66 \%$. The second popular choice tied between reading simplified English books and look up new vocabulary and check pronunciation (26.66\%) while the third was review new grammar points after class (20\%). The next popular choice was practicing the correct pronunciation and new structures with friends and/or family (13.33\%). While there were 11 options provided only 5 were chosen by participants and the rest got $0 \%$. Some of the higher numbers were not expected such as $20 \%$ of students do nothing to improve their English although most of them claimed to like English. Moreover, it seems that students really have different opinion although their situation is the same.

Table 5: What do you do to improve your English?

\begin{tabular}{lc}
\hline I read simplified English books & $8(26.66 \%)$ \\
\hline I watch English programs & 0 \\
\hline $\begin{array}{l}\text { I keep a notebook with all new vocabulary and practice writing them in } \\
\text { sentences }\end{array}$ & 0 \\
\hline I review the new grammar points after class & $6(20 \%)$ \\
\hline $\begin{array}{l}\text { I practice the correct pronunciation and new structures with my friends and/or } \\
\text { family }\end{array}$ & $4(13.33 \%)$ \\
\hline I read articles on the internet & 0 \\
\hline I listen to native speakers reading and/or speaking on the internet & 0 \\
\hline I look up new vocabulary and check pronunciation & $0(26.66 \%)$ \\
\hline I take extra English courses & 0 \\
\hline None of the above & $20(66.66 \%)$ \\
\hline
\end{tabular}

\section{Conclusions}

The overall responses indicate that majority of underprivileged students in this study had positive attitude towards learning English. This reflected in the students' perception that English is important for their future, in which it is a necessity for furthering studies and get better job opportunities. In other words, the students had good impression about learning English and they were aware of the benefits to learn English. Hence, the impression was parallel with the students' attitude towards learning English, which means that the positive attitude was influenced by the positive perception that they possessed.

Furthermore, majority of the students believed that they could improve their English despite of various limitations that they faced as underprivileged students. This reflects the students' confidence in their ability to improve their English language proficiency. The remaining minority, who were in doubt about their ability to get better in learning English as a Second Language (ESL), might be influenced by the factors such as limited resources, opportunities, so on and so forth (Ming, Ling, \& Jaafar, 2011). Even though most of the students have positive feelings towards English, surprisingly they didn't put much effort to improve their English 
proficiency. Therefore, teachers need to assist the students to improve in the related areas of the language by using creative teaching methods that encourages and allows the practices of the language in the classroom) (Choy \& Troudi, 2006). Sooner or later, it will leave a good impact to the students and motivate them to be a better learner of the language.

As for the way to improve the ESL learning process, most of the respondents believed that the need of getting sufficient practice of the language is the essential strategy. They were convinced that their English would improve if they could practice English in their everyday life with others, especially those who spoke English well, and if they were trained in understanding people who spoke English. This need could be fulfilled with the setting up of an English speaking environment/community (Mat \& Yunus, 2014).By having this setup, considerable numbers of activities such as English Speaking Day and competitions could be held to help the students practise English in their daily lives, which in turn would improve their mastery of English as a Second Language (ESL). This can further be enhanced if the set-up is equipped with latest communication technology like multimedia and internet, so that the students could practice communicating online with English native speakers around the world (Ismail, 2008).

In a nutshell, findings of this initial case study provide some basic information about Malaysian underprivileged students' perception and attitude towards learning English as a Second Language (ESL). This preliminary data could help stakeholders of local education system like policy makers, teachers, and parents to think of necessary actions to take in order to help these students learn the language effectively. However, this baseline data need to be enhanced with further research works, so that the phenomenon could be understood in depth and more thorough.

\section{References}

Ahen, J. A. (2009). Student's Perception Towards English For Self Expression. Universiti Malaysia Sarawak. Retrieved September, 22, 2016.

A1-Tamimi, A., \& Shuib, M. (2009). Motivation and attitudes towards learning English: A study of petroleum engineering undergraduates at Hadhramout University of Sciences and Technology. GEMA Online ${ }^{\circledR}$ Journal of Language Studies, 9(2).

Alkaff, A. A. (2013). Students' Attitudes and Perceptions towards Learning English. Arab World English Journal, 4(2).

Campbell, D. T. (1967). Stereotypes and the perception of group differences. American Psychologist, 22(10), 817.

Choy, S. C., \& Troudi, S. (2006). An Investigation into the Changes in Perceptions of and Attitudes Towards Learning English in a Malaysian College. International Journal of Teaching and Learning in Higher Education, 18(2), 120-130.

Eagly, A. H., \& Chaiken, S. (2007). The advantages of an inclusive definition of attitude. Social Cognition, 25(5), 582-602.

Ghazali, S. N. (2016). Learner background and their attitudes towards studying literature. Malaysian Journal of ELT Research, 4(1), 17.

Holmes, J., \& Wilson, N. (2017). An introduction to sociolinguistics. Routledge.

Ismail, R. (2008). Factors affecting less proficient ESL learners' use of strategies for language and content area learning. Universiti Putra Malaysia.

Mat, S. S. C., \& Yunus, M. M. (2014). Attitudes and motivation towards learning English among FELDA school students. Australian Journal of Basic and Applied Sciences, 8(5), 1-8.

Ming, T. S. (2004). Learning English in multicultural Malaysia: Are learners motivated. Journal of Language and Learning, 2(2), 142-153.

Ming, T. S., Ling, T. S., \& Jaafar, N. M. (2011). Attitudes and motivation of Malaysian secondary students towards learning English as a second language: A case study. 3L: Language, Linguistics, Literature ${ }^{\circledR,}$ 17(1).

PENGNATE, W. (2014). Motivation, attitude and English learning behaviours of the low-graded students. TNI Journal of Business Administration and Languages, 2(1), 39-43. 
Yin, R. K. (2001). Case Study Research: design and methods, Thousand Oaks, 3. CA: Sage Publications.

Yunus, M. M., \& Abdullah, N. R. K. R. B. (2011). Motivation and attitudes for learning English among year six students in primary rural school. Procedia-Social and Behavioral Sciences, 15, 2631-2636. 